\title{
The mutational spectrum of Hunter syndrome reveals correlation between biochemical and clinical profiles in Tunisian patients
}

latifa chkioua ( $\square$ chkioualatifa2002@yahoo.fr)

Universite de Monastir https://orcid.org/0000-0002-0538-3552

Oussama Grissa

Universite de Monastir Faculte de Pharmacie de Monastir

Nadia Leban

Universite de Monastir Faculte de Pharmacie de Monastir

Moez Gribaa

Centre Hospitalier Universitaire Farhat Hached de Sousse

Hela Boudabous

Hopital la Rabta

Hadhami Ben Turkia

Hopital la Rabta

Salima Ferchichi

Universite de Monastir Faculte de Pharmacie de Monastir

Neji Tebib

Hopital la Rabta

Sandrine Laradi

Universite de Lyon

Research article

Keywords: Mucopolysaccharidosis type II, Hunter syndrome, clinical features, mutations

Posted Date: October 18th, 2019

DOI: https://doi.org/10.21203/rs.2.16148/v1

License: (c) (i) This work is licensed under a Creative Commons Attribution 4.0 International License. Read Full License

Version of Record: A version of this preprint was published at BMC Medical Genetics on May 24th, 2020. See the published version at https://doi.org/10.1186/s12881-020-01051-9. 


\section{Abstract}

Background: Mucopolysaccharidosis type II (MPS II) or Hunter syndrome is an X-linked recessive lysosomal storage disorder resulting from deficient activity of iduronate 2-sulfatase (IDS ) and the progressive lysosomal accumulation of sulfated glycosaminoglycans (GAGs).

Methods : A diagnosis of MPS II or Hunter syndrome was performed based on the following approach after a clinical and paraclinical suspicion. Two biochemical and molecular tests were carried out separately and according to the availability of the biological material.

Results : All patients in this cohort presented the most common MPS II clinical features. Electrophoresis of GAGs on a cellulose acetate plate in the presence of a high concentration of heparane sulfate showed an abnormal dermatan sulfate band in the patients compared with that in a control case. Furthermore, leukocyte IDS activity ranged from 0.00 to $0.75 \mathrm{nmol} / \mathrm{h} / \mathrm{mg}$ of proteins in the patients. Five previously reported mutations were identified in the study patients: one splice site mutation, c.240+1G>A; two missense mutations, p.R88P and p.G94D; a large deletion of exon 1 to exon 7; and one nonsense mutation, p.Q396*. In addition, two novel alterations were identified in the MPS II patients: one frame shift mutation, p.D450Nfs*95 and one nonsense mutation, p.Q204*. Additionally, five known IDS polymorphisms were identified in the patients: IVS3-16 (c.419-16 delT), p.T214 M (c.641C>T), p.T146T (c.438 C>T), IVS587 (c.709-87G>A), and IVS7+38 (c.1006+38T>C).

Conclusions: The high level of urine GAGs and the deficiency of iduronate 2-sulfatase activity was associated with the phenotype expression of Hunter syndrome. Molecular testing was useful for the patients' phenotypic classification and the detection of carriers.

\section{Introduction}

Hunter syndrome (MPS II; OMIM 309900) is an X-linked recessive inborn error that causes deficient activity of iduronate 2-sulfatase (IDS, EC3.1.6.13). This lysosomal enzyme hydrolyses the 2 sulfate groups of the L-iduronate 2-sulfate units, dermatan sulfate and heparan sulfate [1].

The IDS gene, located on chromosome Xq28, contains 9 exons and is transcribed into a 1400-bp cDNA, which encodes a precursor protein of 550 amino acids [2].

More than 350 different mutations (www.hgmd.org, 2017) in the IDS gene have been reported in patients with Hunter syndrome, including 112 small deletions, 54 altered splicing, 49 gross deletions, 46 small insertions, 19 complex rearrangements, 13 small indels, and 4 gross insertions/duplications [3]

MPS II presents both severe and mild clinical subtypes [1]. The severe phenotype of MPS II, the neuropathic form, is characterized by a progressive clinical deterioration with neurological involvement, multiple dysostoses including joint stiffness, coarse facies including broad noses, macroglossia, and cardiovascular involvement that often leads to death before 15 years of age. Diagnosis is often completed at 3 years of age. Patients with the mild phenotype of MPS II have minimal or no neurological deterioration; they are characterized by joint stiffness and relatively mild somatic changes. In the most attenuated form of MPS II, diagnosis may not be made until 10 years of age, and death may occur in early adulthood; however, some patients have survived until their fifth or sixth decades of life [4].

Based on clinical manifestations of MPS II patients, the biochemical analyses i.e., quantitative and qualitative urinary glycosaminoglycan (GAG) concentration, are usually performed first. This preliminary screening requires a differential diagnosis with the Hurler syndrome (MPS I) for which we obtained the same GAG profile. Thus, the measurement of IDS enzyme activity is necessary to confirm the diagnosis. The genetic test of the IDS gene is important for prenatal diagnosis in MPS II families.

\section{Materials And Methods}

MPS II patients

This is a case series of patients aged 1-39 years old who were recruited from paediatric departments of different hospitals in Tunisia: Tunis, Sousse, Sfax, and Kairouan. Most of the MPS II patients were from a consanguineous marriage. There was no known relationship between the investigated MPS II families.

Our cohorts were subdivided into two groups: P1-P7 for which we had all the biochemical and molecular data and the other group P8-P12 for which we only had the biochemical data because the patients died before our family surveys to perform a genetic analysis. In our hospital, our approach to studying patients with these rare metabolic diseases is as follows: We systematically perform biochemical analyses and the molecular analysis is performed according to the requests of the couples or families at risk; in this case, consent will be provided by these families.

Thus, the families gave informed consent before withdrawal of blood and urine samples and written informed consent was obtained and signed by all studied families: For patients less than 16 years old (P1, P5, P6, P7, P8 and P9), the consent forms were signed by their parents.

In patients older than 16 years (P2, P3, P4, P10, P11 and P12), two subgroups were cited:

In patient who are still alive (P2, P3 and P4), the consent forms were signed by themselves according the available consent form, and in the deceased patients (P10, P11 and P12), the consent forms were signed by themselves when sampling.

This study was approved by the Ethics Committee of the Fahat Hached Hospital Sousse, Tunisia. All procedures were in accordance with the ethical standards of the responsible committee on human experimentation (institutional and national) and with the Helsinki Declaration,

Biochemical diagnosis

Page $2 / 10$ 
The mother and other female members of each family included in the study were examined in order to create a clearer profile of the disease's transmission to facilitate prenatal diagnosis and counselling for MPS II in Tunisia.

Quantitative analysis of total urinary glycosaminoglycans (GAGs)

Urinary GAGs were measured by the dimethylmethylene blue test according to Stone. [5]. The qualitative analysis of urinary GAGs was performed according to Chkioua L. et al. [6].

Enzyme analysis

Leukocyte IDS activity was performed in Biochemistry Laboratory of Hospital Farhat Hached Sousse, Tunisia and was determined as previously described using the artificial substrate 4-methylumbelliferyl- alpha-iduronide-2-sulfate [7].

Molecular analysis and DNA sequencing analysis

Peripheral blood was obtained from patients and genomic DNA was isolated using a standard phenol/chloroform procedure [8]

Each of the 9 exons and introns-exons boundaries of the IDS gene were systematically amplified and sequenced. However, in patients with family history, only the exons were analysed. Primer sequences and annealing temperature are provided in Table 1.

\section{The PCR reactions were performed according to Chkioua et al. [9]. To identify the type and position of the genetic variants, PCR products were purified from excess primers and ddNTP with FavorPrep kit ${ }^{\mathrm{TM}}$ (Favorgen ${ }^{(\mathrm{R})}$ Biotech Corp) and were sequenced in both forward and reverse directions using the same PCR primers with the Big DyeTerminator v1.1 Cycle Sequencing Kit (Applied Biosystems).The resulting products were purified using Illustra MicroSpin G- 50 Columns (GE Healthcare) and electrophoresed on an automated ABI PRISM 310 genetic analyser and interpreted with ChromasPro 2.4.1 software.}

\section{Results \\ Clinical features and biochemical analysis}

The MPS II patients had a clinical diagnosis of Hunter syndrome that was confirmed by biochemical analyses showing a high concentration of urinary GAGs and deficiency in iduronate 2-sulfatase activity in leukocytes.

Biochemical analysis confirmed the diagnosis of all MPS II patients included in the study. The twelve Tunisian MPS II patients in the present study presented low or undetectable levels of IDS activity $(0.00$ to $0.75 \mathrm{nmol} / \mathrm{h} / \mathrm{mg}$ of leukocyte proteins) (Table 3$)$. The electrophoresis profile of urinary GAGs on a cellulose acetate plate is presented in Fig. 1.

The clinical features of each patient are presented in Table 2.

IDS mutation analysis

We analysed the IDS gene of twelve MPS II patients from different regions of Tunisia using PCR, RFLP-PCR, and direct sequencing methods. Clinical and identified genotypes are summarized in Tables 2 and 3.

From the DNA sequencing analysis and RFLP-PCR, two novel mutations and five previously reported mutations were identified (Fig. 2). These included two missense mutations p.R88P (-) Accll and p.G940D (+) Cac8I, one splice site mutation c.240+1G>A (-) Eco64l, one nonsense mutation p.Q396*, and one large deletion skipping the exon 1 to 7 of IDS gene, ex1_7del at position 1307880 (GenBank NT: 019686); the distal deletion breakpoint was located at position 1346697 [10]. The two unreported mutations were p.D450Nfs*95 (-) BamHI and p.Q204* (-) cac8I (Table 3).

Additionally, five known IDS polymorphisms were identified in these MPS II patients: IVS3-16 (c.419-16 delT), p.T214 M (c.641C>T), p.T146T (c.438 C>T), IVS5-87(c.709-87G>A), and IVS7+38(c.1006+38T>C).

\section{Discussion}

Clinical, biochemical and molecular correlations in MPS II patients

All of the data was available for the MPS II patients except for patients P9-P12 for whom only clinical and biochemical data were known because these patients died before their molecular data could be collected. The delay in diagnosis was explained by a lack of awareness among physicians of the specific 
MPS II clinical features associated with the adverse socioeconomic conditions of those patients.

Based on the clinical, biochemical, and molecular data, 6 patients (P1-P4 and P6-7) were classified in the MPS II group with a severe disease, and only one patient (P5) presented a mild phenotype.

According to the clinical data, the confirmation of diagnosis in all MPS II patients was done at a mean age of 5 years, unlike what is found in the literature [1]

The urinary GAG concentration ranged from 30.0 to $116 \mathrm{mg}$ of creatinine, according to the age of each patient. The high level of heparan sulfate in the urine was correlated with the severity of the disease as previously described by Tomastsu S et al.,, who demonstrated a significant correlation between the level of heparan sulfate and the severity of this disease [11]

The leukocyte IDS activity in patients (P1-P4; P6-P8) with the severe type of the disease had a mean of $0.13 \mathrm{nmol} / \mathrm{h} / \mathrm{mg}$ of proteins. Based on the high level of urinary GAGs and the deficiency of IDS activity, a relationship seems to exist between these data and the phenotypic expression of Hunter syndrome, contrasting with what is reported in the literature such as in Filipino patients [12] (Chiong et al., 2017). However, the clinical profiles of the MPS II patients (P1P7) were in agreement with several studies described in the literature, and the clinical manifestations of the phenotype of Hunter syndrome ranged from moderate to severe Hunter syndrome phenotypes [12].

The most recurrent symptoms observed in this series ranged in degree of severity, including hepatosplenomegaly, coarse facial features including broad noses, macroglossia, psychomotor and mental retardation, multiple dysostoses including joint stiffness, oval vertebrae, respiratory problems including otitis, nasal obstruction, and enlarged tongue and adenoids.

Patient P8 was a girl related to Patient P2 who was hemizygous for the p.R88P mutation. She presented GAG excretion of $125 \mathrm{mg} / \mathrm{g} / \mathrm{creatinine}$ and leukocyte IDS activity of $1.00 \%$. She died before molecular analysis was conducted, but she probably had the same genetic mutation as patient $\mathrm{P} 2$ since she presented the same clinical profile as her cousin P2. MPS II females have been noted to present very rare clinical descriptions, and most of them present the severe form of the disease [13]. Importantly, the identification of MPS II heterozygous females by measurement of IDS activity and urinary GAG levels is unreliable. Therefore, the definitive diagnosis should be determined using genetic analysis [14]

Previous studies $[15,16]$ showed that the phenotypic expression of this disease in MPS II females is uncommon, and most of the cases described in the literature presented the severe phenotype. MPS II heterozygous females are rarely reported except for the presence of double mutant alleles or a coincidental genetic defect, leading to skewed X-inactivation or hemizygosity in heterozygotes [17]

Patient P12 was diagnosed at the age of three years old when he had an inguinal hernia operation. However, coarse facial features, including macrocrania, macroglossia and small teeth, had been noted at the age of eighteen months. He presented severe hepatosplenomegaly, skeletal disease, and severe mental retardation. The biochemical test showed that the leukocyte IDS activity in this patient was significantly higher than the enzyme activity of other MPS II patients. Patient P12 presented the severe phenotype of the MPS II disease, but he died before the molecular analysis hence the interest of carrier testing.

In this study, cardiovascular involvement, including arrhythmia and congestive heart failure, was identified in all MPS II patients and has been shown to be the cause of morbidity and mortality in most patients, as has been described previously in the literature [18].

Seven different mutations were found in the 12 MPS II patients. These nucleotides variations reflect the genetic heterogeneity leading to the wide spectrum of clinical phenotypes of MPS II in agreement with several other studies [4,12] (Chiong et al., 2017, Hopwood et al., 1993).

Sequence alterations in the IDS gene included five previously reported mutations and two novel mutations. The severe phenotype was found in patients who had the following mutations: c.240+1G>A, p.R88P, Ex1_7del, and p.Q396*. This in agreement with several previous studies (Table 3).

The missense mutation p.G94D was associated with a milder phenotype. This finding agrees with the data reported in Australian patients [4,19]. This mutation occurred within a conserved amino acid of human lysosomal sulfatase, which is essential for the common sulfatase activity [20].

The first novel alteration p.Q204*(c.610C>T) was a nonsense mutation and was identified in a patient who developed a severe form of MPS II. This mutation was due to a cytosine -to- thymine transversion at position 610 of the cDNA resulting in premature glycopolypeptide truncation at the $204^{\text {th }}$ codon in exon 5 of IDS gene. Carrier testing was performed in the mother, who was found conductive.

The second novel frame shift mutation (p.D450Nfs*95) in exon 9 of the IDS gene is caused by a single-base deletion of guanine at genomic DNA position 1565. This mutation in exon 9 changes codon 450 from aspartic acid (GAT) to a chain termination codon (TAG) that leads to the lack of 95 amino acids at the amino terminus of the IDS protein. This novel mutation may lead misfolding of the glycopeptide resulting in a non-functional protein.

Mutations leading to a premature translation codon have frequently been classified as severe mutations; in agreement with this, the novel frame shift (p.D450Nfs*95) was found in a patient (P6) who presented the severe phenotype.

The p.D450Nfs*95 mutation results in exon skipping and introducing premature translation termination codon in exon nine with an abnormal IDS protein and have been classified as severe mutation. The premature stop codon causes a deletion of the last 5 amino acids of the heavy chain which contains the catalytic core (451455) and the entire light chain (456550) of IDS protein (Fig.3). The predicted premature stop codon could affects protein stability. In fact, the light chain of the IDS protein had an important role in the stability of the protein. Furthermore, the four antiparallel strands comprising the light chain are considerably longer than those of other sulfatases, and hence a greater contribution to the shape of the substrate-binding cleft comes directly from the light chain [21]. The expected severity of this mutation was variable and consequence range from local destabilization and misfolding to global unfolding, leading 
to premature degradation. The K479 residue in the exon 9 was important to the substrate binding [21]. The lack of this residue in our patient (P6) with p.D450Nfs*95 mutation result the nonfonctionnal IDS protein by the absence subtrate binding. Moreover, three too frame shift mutations were described in the exon 9 of IDS gene: p.R443X, p.R443X, p.Y466X and found in the patients who presented severe phenotype [22; 23]. However, investigation of mRNA and expression studies will be necessary to prove this conclusively. Correlation between genotype and phenotype was uncertain using genomic DNA. Further investigations such as transcription tests are useful to predict with confidence the disease phenotype.

In this study, there was no relationship between the genotype and phenotype in these MPS II patients except for the significant correlation between the high level of urine GAGs and the severity of the disease. Future studies with a large number of cases of the same age and genotype are needed to confirm this correlation in MPS II patients.

\section{Conclusions}

In conclusion, this paper provides additional information on the clinical, biochemical and molecular correlations in MPS II patients. Multidisciplinary approaches, such as carrier detection and genetic counselling, are needed for the parents that do not know their IDS genetic profile in order to decrease the prevalence of this inherited pathology and also to prevent the early death of patients.

\section{Declarations}

MPS II: Mucopolysaccharidosis type II, IDS: iduronate 2-sulfatase, GAGs: glycosaminoglycans, HS: heparane sulfate, DS: dermatan sulfate

\section{Declaration}

Ethics approval and consent to participate:

The authors declare that the ethics approval and consent to participate was obtained as indicated in the Methods section of this article.

Consent for publication:

Written informed consent for publication of their clinical details and/or clinical images was obtained from the parents and patients. Copies of the consent forms are available for review by the Editor of this journal.

Availability of data and materials: The datasets used during the current study are available from the corresponding author on reasonable request

\section{Competing interests}

The authors declare that they have no competing interests.

Funding

This work was not financially supported.

Authors' contributions

LC carried out all the experiments, the data analyses, and wrote the manuscript.

$\mathrm{OG}, \mathrm{NL}, \mathrm{MG}$ and $\mathrm{HB}$ supported the analysis and interpretation of the data. HB, SF, NT and SL revised the manuscript.

All authors participated in writing the manuscript and approved the final version.

\section{Acknowledgements: We thank all the families with MPS II for their participation in this study and the clinicians for their participation in this work.}

Authors' information

${ }^{1}$ Faculty of Pharmacy, University of Monastir, ${ }^{2}$ Department of Cytogenetics and Reproductive Biology, Farhat HACHED Hospital Sousse, Tunisia. ${ }^{3}$ Laboratory of pediatrics, La Rabta Hospital Tunis, Tunisia. ${ }^{4}$ The Auvergne-Rhône-Alpes Regional Branch of the French National Blood System EFS/GIMAP-EA 3064, 42100 Saint Etienne, France.

Conflict of Interest Statement

The authors have no conflicts of interest.

\section{References}

1. 1.Neufeld E, Muenzer J, The Mucopolysaccharidoses. , New York: McGraw-Hill (2001) 3421-52. 
2. Wilson P, Morris C, Anson D, Occhiodoro T, Bielicki J, Clements P, Hopwood J: Hunter syndrome: isolation of an iduronate-2-sulfatase cDNA clone and analysis of patient DNA. Proc Natl Acad Sci. 1990;8531-8535.

3. Galvis J, González J, Uribe A, Velasco H: Deep genotyping of the IDS gene in Colombian patients with Hunter syndrome, JIMD Reports, Volume 19, Springer2014, pp. 101-109.

4. Hopwood J, Bunge S, Morris C, Wilson P, Steglich C, Beck M, Schwinger E, Gal A, Molecular basis of mucopolysaccharidosis type II: Mutations in the iduronate-2-sulphatase gene. Hum Mutat. 1993;435-442.

5. Stone J: Urine analysis in the diagnosis of mucopolysaccharide disorders. Ann Clin Biochem. 1998:207-225.

6. Latifa Chkioua, Chaker Aloui, Sandrine Laradi, Oussama Grissa, Hadhami Ben Turkia, Souad Ouesleti, Salima Ferchichi, Abdelhedi Miled, Roseline Froissart: Genetic Heterogeneity of 72 Patients With Mucopolysaccharidosis In Tunisia. IJNTR. 2015: 01-06

7. Voznyi Y.V, Keulemans J, van Diggelen O.P: A fluorimetric enzyme assay for the diagnosis of MPS II (Hunter disease). J inherit metab dis. 2001:675-680.

8. Sambrook J, Fritsch E.F, Maniatis T: Molecular cloning: a laboratory manual, Cold spring harbor laboratory press1989.

9. Chkioua L, Khedhiri S, Ferchichi S, Tcheng R, Chahed H, Froissart R, Vianey-Saban C, Laradi S, Miled A. Molecular analysis of iduronate -2- sulfatase gene in Tunisian patients with mucopolysaccharidosis type II. Diagn Pathol. 2011:23;6:42.

10. Chou YY, Chao SC, Kuo PL, Lin SJ: A $38.8 \mathrm{~kb}$ deletion mutation of the iduronate-2-sulfatase gene in a patient with Hunter syndrome. J Formos Med Assoc.. 2005:273-275.

11. Tomatsu S, Gutierrez MA, Ishimaru T, Peña OM, Montaño AM, Maeda H, Velez-Castrillon S, Nishioka T, Fachel AA, Cooper A, Thornley M, Wraith E, Barrera LA, Laybauer LS, Giugliani R, Schwartz IV, Frenking GS, Beck M, Kircher SG, Paschke E, Yamaguchi S, Ullrich K, Isogai K, Suzuki Y, Orii T, Noguchi A: Heparan sulfate levels in mucopolysaccharidoses and mucolipidoses. J inherit metab dis. 2005:743-757.

12. Chiong MA, Canson DM, Abacan MA, Baluyot MM, Cordero CP, Silao CL. Clinical, biochemical and molecular characteristics of Filipino patients with mucopolysaccharidosis type II-Hunter syndrome. Orphanet J Rare Dis. 2017:7.

13. Young ID, Harper PS, Archer IM, Newcombe RG: A clinical and genetic study of Hunter's syndrome. 1 Heterogeneity. J Med Genet.1982:401-407.

14. Wraith J.E, Beck M, Giugliani R, Clarke J, Martin R, Muenzer J: Initial report from the Hunter outcome survey. Genet Med. 2008:508516.

15. Neufeld E.F, Liebaers I, Epstein C.J, Yatziv S, Milunsky A, Migeon,B.R: The Hunter syndrome in females: is there an autosomal recessive form of iduronate sulfatase deficiency?, Am J Hum Genet. 1977:455.

16. Tuschl K, Gal A, Paschke E, Kircher S, Bodamer OA: Mucopolysaccharidosis type II in females: case report and review of literature. Pediatr Neurol. 2005:270-272.

17. Pinto LL, Vieira TA, Giugliani R, Schwartz IV: Expression of the disease on female carriers of X-linked lysosomal disorders: a brief review, Orphanet J Rare Dis. 2010:14.

18. Kampmann C, Beck M, Morin I, Loehr JP: Prevalence and characterization of cardiac involvement in Hunter syndrome, J Pediatr. 2011:27-331. e2.

19. Bunge S, Steglich C, Zuther C, Beck M, Morris CP, Schwinger E, Schinzel A, Hopwood JJ, Gal A: Iduronate-2-sulfatase gene mutations in 16 patients with mucopolysaccharidosis type II (Hunter syndrome). Hum Mol Genet. 1993:1871-1875.

20. Dierks T, Schmidt B, Borissenko LV, Peng J, Preusser A, Mariappan M, von Figura K: Multiple sulfatase deficiency is caused by mutations in the gene encoding the human $\mathrm{C} \alpha$-formylglycine generating enzyme, Cell. 2003:435-444.

21. Mykhaylo Demydchuk, Chris H. Hill, Aiwu Zhou, Gábor Bunkóczi, Penelope E. Stein, Denis Marchesan, Janet E. Deane, Randy J. Read: Insights into Hunter syndrome from the structure of iduronate-2-sulfatase. Nat Commun. 2017: 8-15786.

22. Flomen RH, Green PM, Bentley DR, Giannelli F, Green EP. Detection of point mutations and a gross deletion in six Hunter syndrome patients. Genomics. 1992: 13:543-50

23. Broadhead DM, Kirk JM, Burt AJ, Gupta V, Ellis PM, Besley GT. Full expression of Hunter's disease in a female with an X-chromosome deletion leading to non-random inactivation. Clin Genet. 1986, 30:392-8.

24. Froissart R, Maire I, Millat G, Cudry S, Birot AM, Bonnet V, Bouton O, Bozon D: Identification of iduronate sulfatase gene alterations in 70 unrelated Hunter patients. Clin Genet. 1998:362-368.

25. Villani GR, Balzano N, Grosso M, Salvatore F, Izzo P, Di Natale P: Mucopolysaccharidosis type II: identification of six novel mutations in Italian patients. Hum mutat. 1997:71.

\section{Tables}

Table 1: Biochemical, clinical and molecular MPS II profiles in Tunisian patients

1Urine GAGs : normal value GAGs

*: at position 1307880 (GenBank NT:019686), and the distal deletion breakpoint was located at position 1346697

$\mathrm{N}$ : Normal sequence; M: Mutated sequence

?: According to his phenotype, it can be presumed that the P8 was homozygous for p.R88P mutation 


\begin{tabular}{|c|c|c|c|c|c|c|c|c|c|c|c|c|}
\hline $\begin{array}{l}\text { Number of } \\
\text { cases }\end{array}$ & $\mathrm{P} 1$ & $\mathrm{P} 2$ & P3 & $\mathrm{P} 4$ & P5 & P6 & P7 & P8 & P9 & P10 & $\mathrm{P} 11$ & P12 \\
\hline Sex & $\mathrm{M}$ & $\mathrm{M}$ & $\mathrm{M}$ & M & M & $\mathrm{M}$ & $\mathrm{M}$ & $\mathrm{F}$ & $\mathrm{M}$ & M & M & $\mathrm{M}$ \\
\hline Consanguinity & unrelated & $\begin{array}{c}\text { 1st } \\
\text { cousins }\end{array}$ & $\begin{array}{c}\text { 3rd } \\
\text { cousins }\end{array}$ & unrelated & 1st cousins & unrelated & unrelated & $\begin{array}{c}1 \text { st } \\
\text { cousins }\end{array}$ & unrelated & unrelated & unrelated & $\begin{array}{c}1 \text { st } \\
\text { cousins }\end{array}$ \\
\hline Origin & Tunis & Sfax & Kairouan & Sousse & Tunis & Sfax & Beja & Monastir & Sousse & Sousse & Mahdia & Sousse \\
\hline $\begin{array}{l}\text { Urine GAGs }{ }^{1} \\
\mathrm{mg} / \mathrm{g} / \mathrm{creatinine}\end{array}$ & 93.4 & 30.0 & 95.0 & 48.0 & 56.8 & 105 & 116 & 125 & 28.4 & 65.8 & 23.3 & 83.9 \\
\hline $\begin{array}{l}\text { Age at } \\
\text { diagnosis } \\
\text { (years/months) }\end{array}$ & 4 & $1 / 6$ & 4 & 6 & 3 & $4 / 2$ & 4 & 3 & 2 & 3 & 9 & 12 \\
\hline Age (years) & 4 & 18 & 22 & 26 & 5 & 5 & 7 & $\begin{array}{l}9 \\
\text { (died) }\end{array}$ & $\begin{array}{l}9 \\
\text { (died) }\end{array}$ & $\begin{array}{c}19 \\
\text { (died) }\end{array}$ & $\begin{array}{c}29 \\
\text { (died) }\end{array}$ & $\begin{array}{l}39 \\
\text { (died) }\end{array}$ \\
\hline $\begin{array}{l}\text { Leucocytes IDS } \\
\text { activity } \%\end{array}$ & 0.20 & 0.20 & 0.50 & 0.00 & 0.750 & 0.00 & & 0.39 & 0.059 & 0.00 & 0.65 & 1.5 \\
\hline Mutations & $\begin{array}{c}\text { IVS2+1 } \\
\mathrm{G}>\mathrm{A}\end{array}$ & p.R88P & Ex1_7del & p.Q396* & p.G94D & p.D450Nfs*95 & p.Q204* & p.R88P? & $\begin{array}{l}\text { None } \\
\text { found }\end{array}$ & $\begin{array}{l}\text { None } \\
\text { found }\end{array}$ & $\begin{array}{l}\text { None } \\
\text { found }\end{array}$ & $\begin{array}{l}\text { None } \\
\text { found }\end{array}$ \\
\hline Location & $\begin{array}{c}\text { INTRON } \\
2 \\
\end{array}$ & EXON 3 & * & EXON 9 & EXON 3 & EXON9 & EXON 5 & EXON 3 & & & & \\
\hline $\begin{array}{l}\text { Restriction } \\
\text { enzyme }\end{array}$ & $\begin{array}{c}(-) \\
\text { ECO64I }\end{array}$ & $\begin{array}{l}(-) \\
\text { ACC II }\end{array}$ & - & (-) Cac8I & (-) BseNI & (-) BamHI & (-) Cac8I & (-) ACC II & \multirow{4}{*}{\multicolumn{4}{|c|}{$\begin{array}{l}\text { These patients were dead before our } \\
\text { molecular analysis. }\end{array}$}} \\
\hline $\begin{array}{l}\text { Fragment length } \\
\text { (bp) }\end{array}$ & $\begin{array}{l}\text { N: } 373 \\
\text { M: } \\
180+193\end{array}$ & $\begin{array}{l}\mathrm{N}: \\
91+432 \\
\mathrm{M}: 523\end{array}$ & - & $\begin{array}{l}\mathrm{N}: \\
49+54+119+333 \\
\mathrm{M}: 95+119+173\end{array}$ & $\begin{array}{l}\mathrm{N}: \\
37+46+109+331 \\
\mathrm{M}: 37+155+331\end{array}$ & $\begin{array}{l}\text { N: } 137+303 \\
\text { M: } 440\end{array}$ & $\begin{array}{l}N: 200+ \\
280\end{array}$ & $\begin{array}{l}\mathrm{N}: \\
91+432 \\
\mathrm{M}: 523\end{array}$ & & & & \\
\hline Status & reported & reported & reported & reported & reported & Novel & Novel & reported & & & & \\
\hline Reference & {$[24]$} & {$[25]$} & {$[10]$} & [ 24] & {$[4]$} & This report & $\begin{array}{l}\text { This } \\
\text { report }\end{array}$ & [ 25] & & & & \\
\hline Phenotype & severe & severe & Severe & severe & Mild & severe & severe & severe & & & & \\
\hline
\end{tabular}

\begin{tabular}{|c|c|c|c|c|c|c|c|c|c|c|c|c|}
\hline MPS II patients & P1 & \multicolumn{2}{|l|}{ P2 } & P4 & P5 & P6 & P7 & P8 & P9 & P10 & P11 & P12 \\
\hline Age at diagnosis (year/month) & 4 & \multicolumn{2}{|l|}{$1 / 6$} & 6 & 3 & $4 / 2$ & 4 & 3 & 2 & 3 & 9 & 12 \\
\hline Age (years) & 4 & \multicolumn{2}{|l|}{18} & 26 & 5 & 5 & 7 & $\begin{array}{l}9 \\
\text { (died) }\end{array}$ & $\begin{array}{l}9 \\
\text { (died) }\end{array}$ & $\begin{array}{l}19 \\
\text { (died) }\end{array}$ & $\begin{array}{l}29 \\
\text { (died) }\end{array}$ & 39 (died) \\
\hline \multicolumn{13}{|c|}{ Reccurant clinical symptoms } \\
\hline Hepatosplenomegaly & ++ & ++ & ++ & ++ & + & ++ & ++ & ++ & ++ & ++ & & ++ \\
\hline $\begin{array}{l}\text { Coarse facies : Broad noses, } \\
\text { Macroglossia }\end{array}$ & ++ & ++ & ++ & ++ & ++ & ++ & ++ & ++ & ++ & ++ & ++ & ++ \\
\hline Cranial dysmorphism : macrocrania & ++ & +++ & +++ & ++ & ++ & ++ & ++ & + & ++ & ++ & ++ & ++ \\
\hline Psychomotor retardation & ++ & +++ & +++ & ++ & + & ++ & +++ & ++ & +++ & +++ & ++ & ++ \\
\hline $\begin{array}{l}\text { Dysostosis multiple : joint stiffness } \\
\text {, oval vertebrae }\end{array}$ & ++ & +++ & +++ & ++ & ++ & ++ & +++ & +++ & +++ & +++ & +++ & +++ \\
\hline Osteopenia & ++ & ++ & ++ & ++++ & ++ & +++ & ++ & ++ & ++ & ++ & +++ & \\
\hline Mental retardation & ++ & +++ & ++ & ++ & + & ++ & ++++ & ++ & & & & ++ \\
\hline $\begin{array}{l}\text { Respiratory problems: otitis, nasal } \\
\text { obstruction, enlarged tongue and } \\
\text { adenoids. }\end{array}$ & ++ & ++ & ++ & ++ & ++ & ++++ & ++++ & ++ & ++ & ++ & ++ & ++ \\
\hline $\begin{array}{l}\text { Cardiovascular involvement: } \\
\text { arrhythmia and congestive heart } \\
\text { failure }\end{array}$ & ++ & ++ & ++ & ++ & +++ & + & ++++ & ++ & ++ & ++ & ++ & ++ \\
\hline Corneal clouding & - & - & - & -- & - & ++ & - & - & - & - & - & - \\
\hline \multicolumn{13}{|c|}{ Specific clinical symptoms } \\
\hline & $\begin{array}{l}\text { Multiple } \\
\text { hernia }\end{array}$ & & & $\begin{array}{l}\text { Blood smear } \\
\text { shows an } \\
\text { overload }\end{array}$ & $\begin{array}{l}\text { Blood smear shows } \\
\text { an overload } \\
\text { Dysphasia }\end{array}$ & & $\begin{array}{l}\text { Skin } \\
\text { involvement }\end{array}$ & & & & & $\begin{array}{l}\text { Rhinorrhea umbilical } \\
\text { hernia }\end{array}$ \\
\hline
\end{tabular}

Table 2: Clinical findings of the MPS II patients 
Table 3: Primers for PCR and DNA sequencing for detection of IDS mutations

\begin{tabular}{|c|c|c|c|}
\hline Primer & Sequence $5^{\prime}>3^{\prime}$ & $\operatorname{Tm}\left({ }^{\circ} \mathrm{C}\right)$ & Expected products $(\mathrm{bp})$ \\
\hline F1-IDS & GAGGAGGTCTCTGTGGCTGC & 63.5 & \multirow[b]{2}{*}{376} \\
\hline R1-IDS & AGGGACGGTAGGAAGGAGTG & 61.4 & \\
\hline F2-IDS & CACTCACTATCTCGCTTCCTC & 59.8 & \multirow[b]{2}{*}{540} \\
\hline R2-IDS & CCTCTAACAAGATGTCCCG & 56.7 & \\
\hline F3-IDS & GGTTACCTAAGAGATGGCAG & 57.3 & \multirow[b]{2}{*}{542} \\
\hline R3-IDS & CAGCCTGTGTCCTCССТАC & 61.0 & \\
\hline F4-IDS & GTAGATGAGGAAACTGAGCC & 57.3 & \multirow[b]{2}{*}{475} \\
\hline R4-IDS & CTATTCAATGAGTCTGACACG & 55.9 & \\
\hline F5-IDS & GCCTGGAAAACAAGAAACACC & 57.9 & \multirow[b]{2}{*}{487} \\
\hline R5-IDS & TGGCGATGGCAGGATGTAG & 58.8 & \\
\hline F6-IDS & AGGCAGGAGGTGGGGACAG & 63.1 & \multirow[b]{2}{*}{607} \\
\hline R6-IDS & CCAGCACTTTGCCTGATAACTC & 60.3 & \\
\hline F7-IDS & CTAAGGGGTAGGGATTGGGAG & 61.8 & \multirow[b]{2}{*}{440} \\
\hline R7-IDS & ACCCACACCTATCCGTCAAGC & 61.8 & \\
\hline F8-IDS & GGTGATGAGTTTCTACTTCCT & 55.9 & \multirow[b]{2}{*}{465} \\
\hline R8-IDS & GAGATGTTCAGAAAGCGTG & 54.5 & \\
\hline F9-IDS & GTGAGGTGCCGAGGTGGTG & 63.1 & \multirow[b]{2}{*}{468} \\
\hline R9-IDS & GGTGCGTATGGAATAGCCC & 58.8 & \\
\hline f9-IDS & CTTCAGACATCCCTCAGTGG & 95.4 & \multirow[b]{2}{*}{283} \\
\hline r9-IDS & GCTCTAАСТССТССТСТСАСС & 61.8 & \\
\hline
\end{tabular}

\section{Figures}




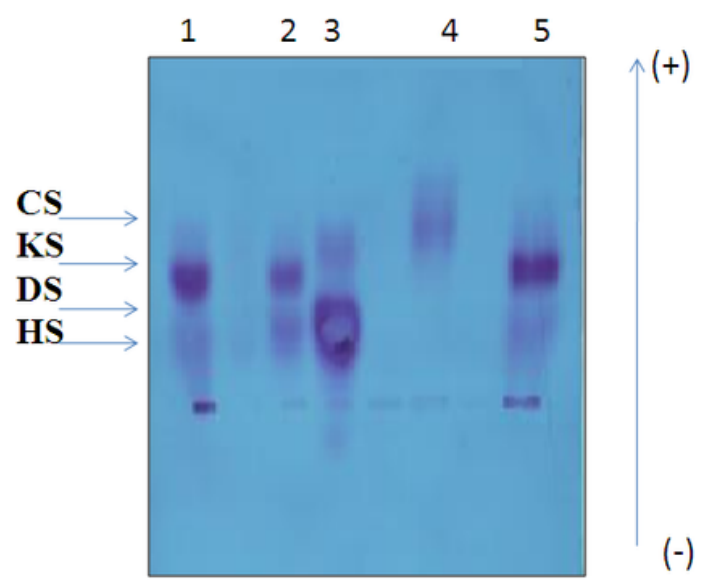

Figure 1

MPS II electrophoresis profile on a cellulose acetate plate of urinary GAGs. 1, 3 and 5: MPS II patients; 3: MPS III patients; 4: Control case; CS: chondroïtin sulphate; DS: dermatan sulphate; HS: heparan sulphate.
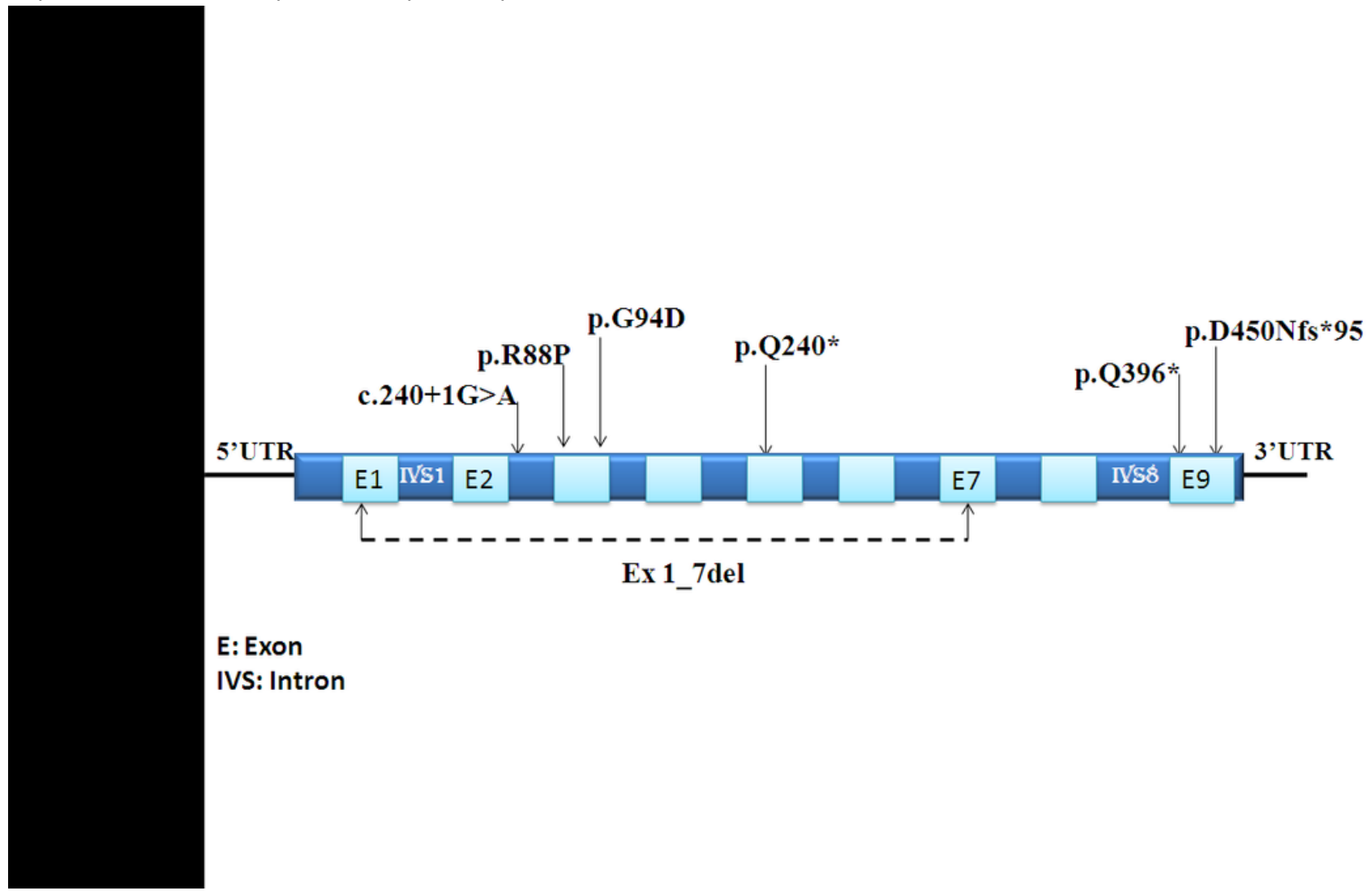

\section{E: Exon}

IVS: Intron

Figure 2 


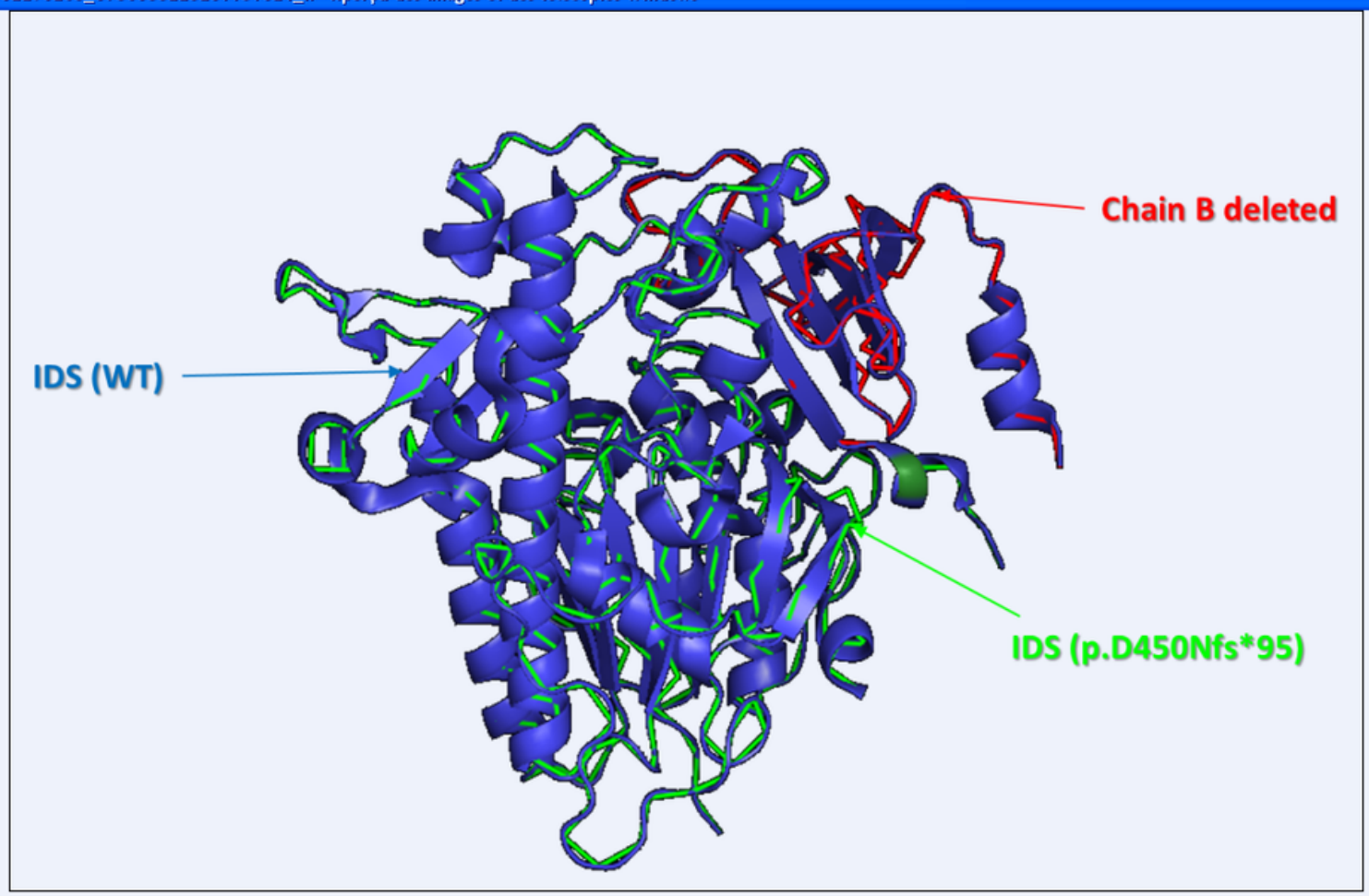

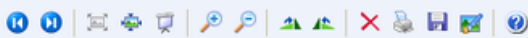

\section{Figure 3}

Structural superposition of wild type (blue) and the p.D450Nfs ${ }^{*} 5$ mutated IDS protein (green). The deleted part of the mutate protein (red) correspond the Cterminal of the heavy chain ( 5 amino acids) and the all part of the light chain $(14 \mathrm{KDa})$. pdb $=5 \mathrm{FQL}$. 